\title{
Exploring Rata Yakuma: Weaving Dance/Movement Therapy and a Sri Lankan Healing Ritual
}

\section{探索Rata Yakuma仪式:舞蹈/动作治疗与斯里兰卡式治疗仪式的交织}

\author{
Ashley Fargnoli ${ }^{1}$ and Dhanushka Seneviratne ${ }^{2}$ \\ ${ }^{1}$ Resilience Refuge, USA/Sri Lanka \\ ${ }^{2}$ University of Kelaniya, Sri Lanka
}

\begin{abstract}
In the South Asian nation of Sri Lanka, dance-based rituals that promote healing for physical and psychological illnesses continue to be implemented island-wide. In this article, the Sri Lankan and American coauthors discuss their embodied exploration that resulted from almost two years of onsite collaboration in Sri Lanka, specifically their investigation of the low-country Rata Yakuma ritual performed for women experiencing pregnancy or infertility. We explored its relevance for community and personal wellbeing as well as potential intersections with dance/ movement therapy. We discuss our experiences of being self-reflective while learning from each other and practicing cultural humility when adapting movements from ritual practices. Themes of finding strength, stability, sense of home, connecting with nature, increased connection to certain body parts, and shifting emotions all resulted from the collaborative process. The process culminated in a dance film to further express our embodied reflections, which can be viewed here: https://vimeo.com/581258415/5d941344d3.
\end{abstract}

Keywords: Dance/movement therapy, Sri Lanka, Rata Yakuma, Low-country dance, Cross-cultural collaboration

\section{摘要}

在南亚国家斯里兰卡，以舞蹈为基础的促进身体和心理疾病治疗的仪式在全岛持 续推广。本文中，斯里兰卡和美国的合著者们讨论了他们在斯里兰卡近两年的实地合作 中所进行的具身性探索，特别是他们对为经历怀孕或不孕的妇女举行的低地 Rata Yakuma仪式的调查。合著者们探索了该仪式与社区和个人福祉的相关性，以及与舞蹈/ 动作治疗的潜在交叉点。他们还讨论了他们在相互学习的同时进行自我反思的经验， 以及在从仪式实践中调整动作时实践文化谦卑的经验。找寻力量、稳定和家园感的主 题；与自然的联系；与身体某些部位联系的增强；以及情绪的转变，都是在这一 合作过程中产生的结果。这个过程在一部舞蹈电影中达到了高潮，以进 一步表达其具身性的反思，影片可以在这里观看:https://vimeo.com/581258415/5d9 41344d3。

关键词: 舞蹈/动作治疗，斯里兰卡, Rata Yakuma仪式, 低地舞蹈, 跨文化合作 


\section{Introduction}

The South Asian island nation of Sri Lanka has thousands of years of rich and diverse healing dance and ritual practices. In this article, a Sri Lankan dancer and university lecturer and an American dance/movement therapist document their mutual desire to learn from each other through embodied practice. The Sri Lankan coauthor has more than 25 years of dance training and has been learning about potential applications of dance/movement therapy (DMT) with diverse populations in Sri Lanka, particularly within educational dance settings. The American coauthor is a dance/movement therapist and has been living, teaching, and studying in Sri Lanka for almost two years while training in various Sri Lankan dance forms. This collaboration grew from shared academic exchange, mutual mentorship, and friendship over the course of two years. Through this collaboration, the coauthors explored a specific ritual from the low-country (Pahatha rata) dance form, one of the three Sinhalese dance forms in Sri Lanka, and the potential intersections with DMT as it is practiced in the West.

The process was rooted in authentic exchange and guided by both Eastern and Western approaches to movement. Owing to Sri Lanka's post-colonial and post-war context, we tried to remain cognizant of potential power dynamics that can come into play when Western DMT practitioners enter spaces in which dance healing rituals have been practiced for thousands of years. Through coauthorship, codesign, and collaboration, we aimed to focus on our collaborative authentic process of learning from each other while documenting the questions that arose along the way.

The creative art therapies are emerging in Sri Lanka; drama therapy and art therapy are currently the most established. Interest in DMT, from both the fields of psychology and dance, is growing rapidly. Professionals from each respective field, including these authors, are curious whether or not DMT can integrate within existing Sri Lankan structures and frameworks. Although mental health treatment is still stigmatized in Sri Lanka, a strong and dedicated network of mental health professionals is growing. Healing rituals are still present across the island to address both physical and psychological issues; however, these practices are becoming less prevalent and are often held in more theatrical and performative settings.

Although this article is not research, the main goal of this article was to use this first exploration as a stepping stone to more formalized research in the future. That said, two overarching questions, taking into account our experiences within the psychology and dance education communities in Sri Lanka, helped to guide our initial exploration:

- Are there any DMT techniques and approaches that could be applicable within the education sector and the way dance pedagogy is approached in Sri Lanka?

- Are there movements, aesthetics, and elements from low-country dance healing rituals that could inform the way DMT sessions in Sri Lanka are facilitated in a culturally sensitive way? 


\section{Literature Review}

\section{An Overview of Sri Lankan Dance}

The dances of Sri Lanka's indigenous Wanniyala-aetto community (meaning "those of the forest"), often referred to as the Veddah by non-indigenous populations, are considered to be the first ritual dances on the island. Their rituals, which are preBuddhist and deeply connected to the forest and the natural environment, focused on "supernatural powers of natural phenomenal, weather conditions and illnesses, which were personified in divine images together with the sun, mood and fire god" (Rajapakshe, 2004, p. 66).

With the arrival of Buddhism to Sri Lanka in the third century B.C. and the planting of the bodhi sapling, features of Buddhism were woven into existing healing rituals. Drumming and dancing at Buddhist religious ceremonies became more common and even compulsory in some places (Rajapakshe, 2004). The Kohomba Kankariya, for example, a well-known practice from the central hill country region of Kandy, is based on a ritual that was performed over 2000 years ago for one of Sri Lanka's first kings, Panduva, who was cursed by the demon princess Kuveni (Reed, 2010). Today, the Kohomba Kankariya continues to be practiced for "forgiveness, generosity, and peace" and can be described as "restoring human community...in a collective rite of healing" (Reed, 2010, p. 23). Classified as a shantikarma ritual, or a peace-making ritual, it is performed by a ritual priest in benefit of the participants (Rajapakse, 2004) and includes elements from Veddah practices (Reed, 2010). Other rituals of note that are rooted in dance include the bali ritual, which weaves pre-Buddhist, Hindu, and Buddhist elements when "planetary deities become malevolent" (Lasanthi Dona, 2016, p. 124) as well as tovil, exorcism rituals directed toward devils or demons who have inflicted physical and psychological illness.

From these ritual practices, three Sinhalese dance forms developed in Sri Lanka. Kandyan dance (Udarata natum), born in the Central hill country region and based on the Kohomba Kankariya ritual, is one of the most well-known and considered Sri Lanka's "national dance." Low-country dance (Pahatha rata natum) from the southern and southwestern coastal regions and Sabaragumuva dance (Sabaragamuw natum) from the southwestern interior regions of Sri Lanka constitute the other two dance forms. These traditional dance styles originated via different rituals.

The South Indian dance form of Bharata Natyam began appearing in Sri Lanka in the early $20^{\text {th }}$ century among minority Tamil communities with the reemergence of Tamil culture and language during the anti-colonial movement in Sri Lanka. With the influence of the Kalakshetra school of Bharata Natyam, this dance form began to appeal to the diverse inhabitants of Colombo, including Buddhist Sinhalese populations. In fact, the popularity of Bharata Natyam influenced the development of Kandyan dance (Satkunaratnam, 2013).

Another Tamil practice, Kooththu, although often considered a theater ritual, weaves rhythmic drumming, dance, songs, and storytelling and was widespread in the northern and eastern sections of the country. This practice, which dates from the $17^{\text {th }}$ or 
$18^{\text {th }}$ century, was revived and reformed during the later stages of the civil war, after a time in which Tamil communities were not able to fully practice this art form (Gladding, 2012). Jeyasankar Sivagnanam was integral in helping with the reformulation of this practice in the eastern section of Sri Lanka. The stories, which draw on mostly Hindu myths and epics, have been contemporized by the post war context and current themes arising in the community. All members of the community, from the elders who held the history of the stories, to the youth, engaged in developing performances to bring about a sense of community (Third Eye Local Skills and Knowledge Group, 2012). The innate healing provided among all of these practices, despite the diverse origins and communities, shows the importance of the therapeutic value of movement across the island throughout history.

\section{The Rata Yakuma ritual}

Rata Yakuma (also known as Riddi Yagaya) is a low-country dance ritual and was the focus of our collaborative exploration and video as well as the thematic explorations in the DMT sessions. The Rata Yakuma ritual has a special place in the worship of devils in the lowlands of Sri Lanka. The main purpose of the ritual is to exorcise demons that have led to difficulty around childbirth and pregnancy, including preventing miscarriages and stillbirths, assuring a smooth delivery as well as addressing infertility (Jayatunge, 2017). Although the ritualis geared toward women, to date, all of the dance rituals in Sri Lanka have been performed by men.

The focus of the ritual offerings are to Queen Riddi, who was born in the Rangiri Fort in the city of Willodi. Riddi is a group of seven queens, who are also referred to as the barren (childless) queens. This ritual helps to foster the connection between a child and the outside world through the following dance patterns: Nanumura (12 movements of bathing), Kapu Upatha (planting of cotton, cutting leaves, drying them, and viewing the cloth to offer to Dipankara Buddha for blessings), and Daru Nelavilla (taking care of the newborn).

The Nanumura episode of the ritual is a solo dance. The male dancer dresses up in decorated white costumes, including a blouse, hair wig, red cloth, earrings, and a necklace. The wares are made with gop kola, or young coconut leaves. Gop carving is a practical technique for this occasion. The jewelry is beautifully crafted by the dancers based on their past experiences and practice.

The Nanumura ritual pattern of the queens includes 12 pelapalis (dance patterns that connect different movements) to describe how the queens were preparing for the salu wiwima (viewing of the cloth). These movements include bathing, anointing nапu (herbal remedies) on the head, applying soap, applying sandalwood, applying eyeliner, wearing salu (clothes), wearing earrings (thodu), combing hair, wearing the necklace (thalli), wearing bangles (walalu), wearing hairpin (kura), and wearing hair wig (saawariya). Finally, the dancer looks at all of these elements in the mirror.

The therapeutic elements embodied in the Nanumura procession are embedded not only in the dance forms, but also in the whole process of the ritual, including the singing 
and drumming. Below is an excerpt from the Kavi gayanaa, or one of the chants that accompanies this part of the ritual:

Dambadiwu himayathula-rangiri kuta widu thula... Wesena bisawun kala-nanu mura mangallayayak asalola. (The queens who live in Rangirikuta — please listen to nanu mura mangalyaya)

Ran vila riddhi wila kelina bisawunta Manik vile diya naalaa goda enta... Ayawana puda panduru heppuwa-purawanta... Ranruwa sema bisowaru yahaninenta...Aaa...Aaa

(Queens who play in the gold and silver lake. Come and soak yourself in the lake of gems. Your heppuwa (a traditional tier to serve beetle leaves to welcome guests) is filled with loads of offerings. Glorious queens, walk out of the bed)

Aladola pinaala goda enawa-naala bisawun konde bandinawa Bisawun sele rali allanawa - rali alla sudu sela andinawa (After bathing, the queens were wearing the sela white cloth)

Athe ranwallau athala geneya - kane eran puskola la geneya Gane dodalle enaa-peneya-ane tikiri kumari-saamineya (After bathing, the queens were wearing bangles and earrings)

Alsawariy genna nithi sarsenne-pil monariya karaluwa sewanna Malmonariya se karawata dilisenne -mal mada anagi ruwa nayaka bisawunne (After bathing, the queens were wearing hair wigs)

Furthermore, this ritual is considered a village healing practice, and movements are adapted according to the needs of the patient. Fear is dealt with differently in this ritual; instead of trying to scare the patient like in other rituals, the ritual priest wants to decrease the fear that is connected to society, illness, and mental schema and increase their capacity for happiness (Widhanagamage, personal communication, April 10, 2020). The psychological aims of the ritual are achieved through dancing, singing, drumming, along with dramatical movements, improvisation, and dialogues.

\section{Our Process of Collaboration}

\section{Initial Ceremony (Ashirwada Pooja)}

Our collaborative journey began with an Ashirwada pooja, a ceremony to invoke blessings. This ceremony begins the process of learning a dance form in Sri Lanka. The pooja was conducted at the home of the American coauthor. Also present at the Ashirwada pooja were two Kandyan dance teachers (Dhananjaya Jayawardene and Vajira Mantillake; Figure 1C), as the American coauthor also started learning the Kandyan dance tradition at this time. The focus of this article, however, is solely on the 


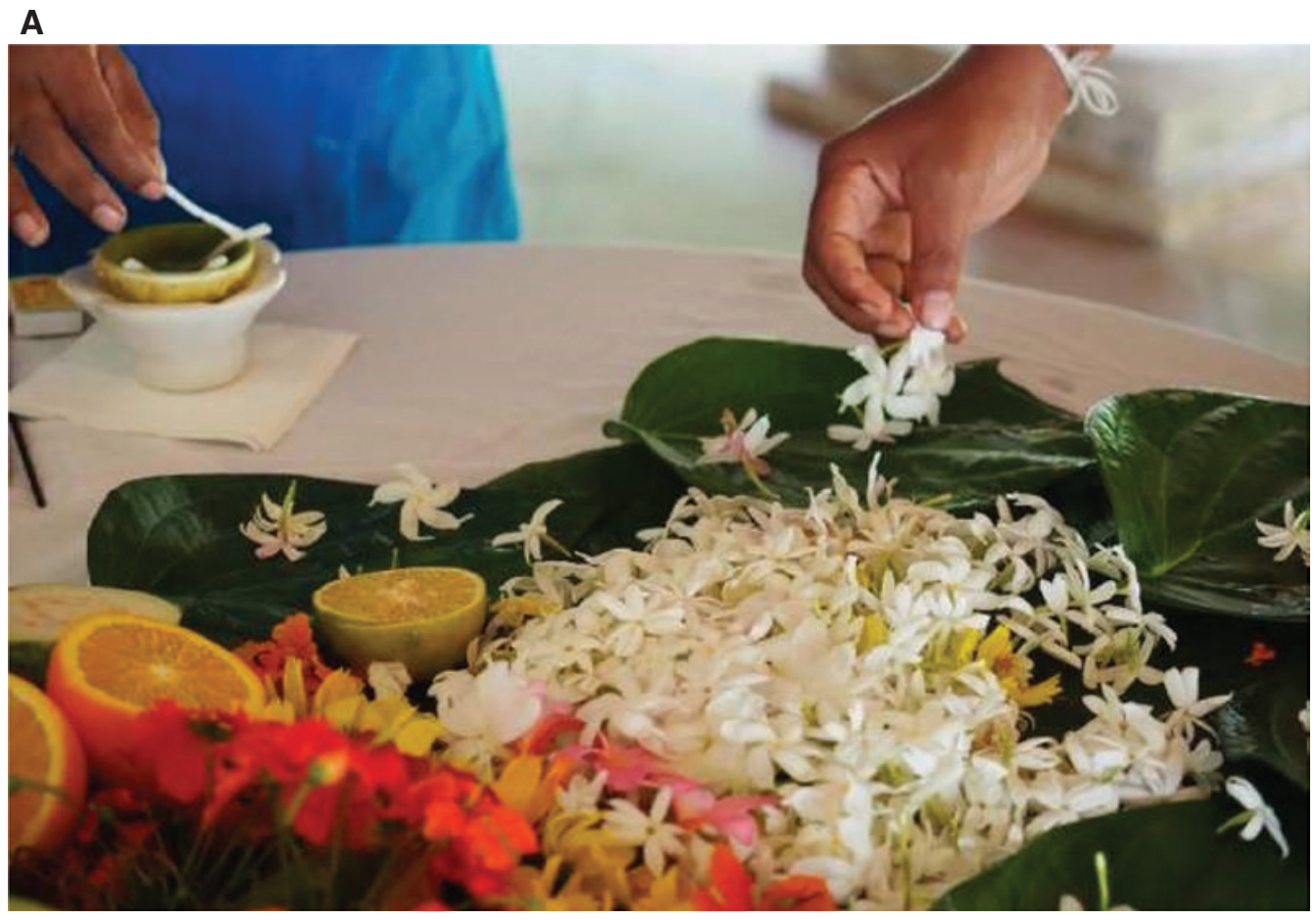

\section{B}

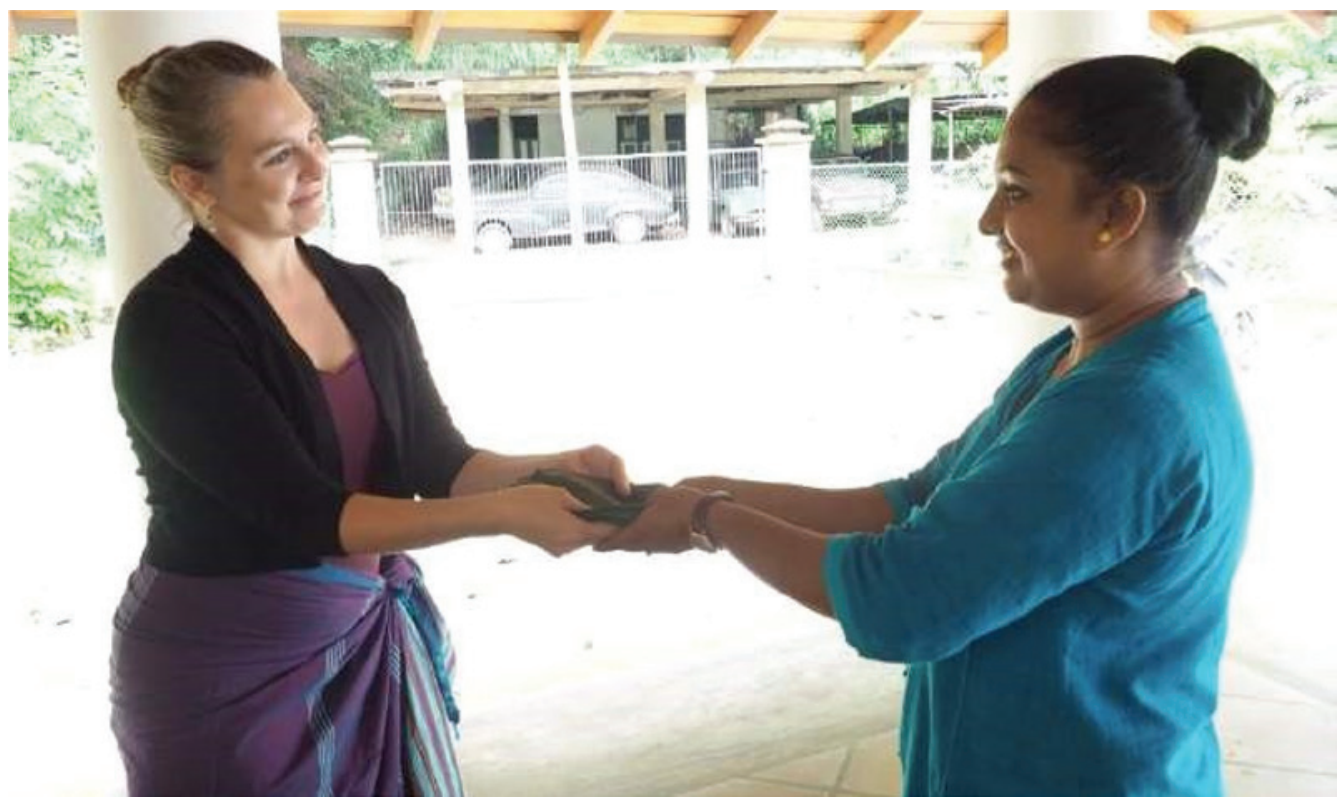

FIGURE $1 \mid$ (Continued) 


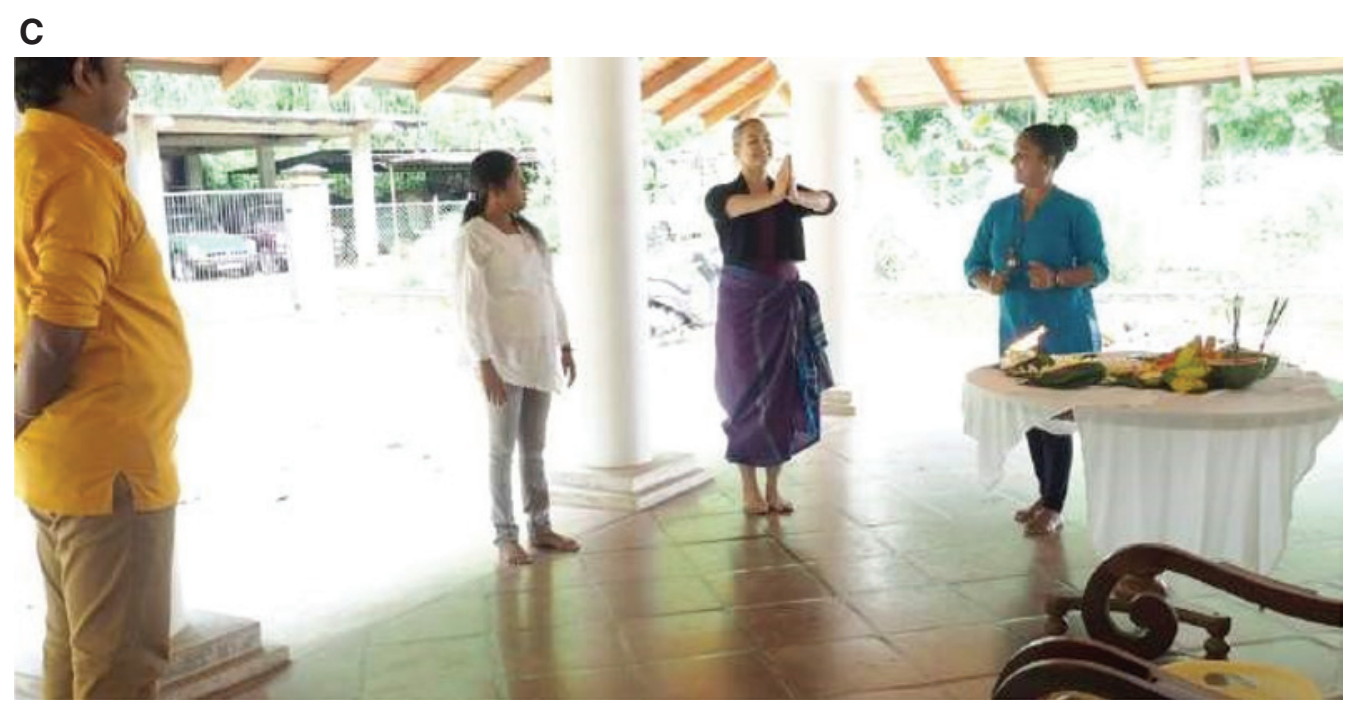

FIGURE 1 | Initial ceremony (Ashirwada Pooja): (A) preparing the ceremonial offering; (B) exchange of betel leaves during the Ashirwada Pooja; (C) performing the namasakara. From left to right: Dhananjaya Jayawardene, Vajira Mantillake (Kandyan dance teachers), Ashley

Fargnoli, and Dhanushka Seneviratne (the coauthors).

exploration and collaboration of the two coauthors and their exchange of learning and teaching low-country dance and DMT. The Kandyan dance classes were held separately and will be further discussed in future writings.

In earlier days, students would go to the guru's house to learn dance and would bring fruits, sweetmeats, kokis (fried, crispy snack), and other items that they had with them instead of money. They would give betel leaves, worship the guru, and ask them to teach dance in the guru kula system (the tradition of learning at the teacher's house where the student would also stay). The teacher would check the student's birth time and decide whether or not they were suitable to give shilpa, or the process of imparting the foundational skills. Only then could the student enter the guru kula. Once entering, the student worships Lord Buddha and the gods. At the auspicious time, the teacher would teach the first foot movement (paa saramba). These steps are passed on from one guru parampara generation to another. After, the student would stay at the teacher's home for years to learn the dance form. Because of COVID-19 and the time restraints of both authors in this contemporary world, it was not possible for the American coauthor to stay at the Sri Lankan's author's house, but they completed the pooja ceremony in person to the best of their ability to align with the traditional practice (Figure 1).

\section{The Structure}

Following the Ashirwada pooja ceremony, the coauthors held two sessions in person and then continued with online sessions due to the increasing COVID-19 cases in Sri 
Lanka. In the initial sessions, the Sri Lankan coauthor taught foundational elements of low-country dance, and the American coauthor provided an introduction to DMT. Some of the foundational low-country dance training included learning the namaskara, or opening salutary movement that the dancer does to pay reverence to the Buddha, guru, parents, and earth; the mandiya, the basic dance position from which all of the dance movements in Sinhalese dance are performed, achieved by placing the feet three steps away from one another while bending the knees and maintaining the basic position; gaman matra, or the walking patterns; ilangam saramba, or basic footwork and hand movements; and irattiya, or movement to end a phrase.

Starting in February 2021, we decided to focus solely on the Rata Yakuma lowcountry ritual. We held an additional 12 sessions over the course of three months. We started with a low-country dance class, followed by a short break, and then a DMTbased session. The low-country classes focused on learning the history of the Rata Yakuma ritual, chanting kaviya, and learning sections of the ritual. As it would be impossible to learn the entire ritual, which often lasts up to 12 hours and takes years of learning from ritual priests, we decided to focus on one section that documents the preparation for an offering to Lord Buddha.

In the DMT-based sessions, the American coauthor led techniques from various DMT approaches. Her framework is rooted in over a decade of working alongside trauma survivors, including refugees and survivors of human trafficking, in conjunction with her training and experiences of DMT in India with Sohini Chakraborty, where she was first introduced to DMT. She facilitated a session based in Authentic Movement, a DMT intervention developed by Mary Stark Whitehouse and Janet Adler, in which the mover moves with their eyes closed and follows internal impulses while a witness (facilitator) witnesses the movement improvisation (Pallaro, 1999). The American coauthor adapted the Authentic Movement process of witnessing to be cognizant of power dynamics, a topic of discussion in Ebony Nichols' (2019) pivotal DMT master thesis, which focused on the importance of recognizing and identifying the unconscious movement blind spots for therapists that are working alongside cultures that are not their own. Nichols' thesis served as a point of reflection and reference throughout the process, in particular for the American dance/movement therapist. Her work greatly informed how we shaped our inquiry and helped guide action steps to work toward creating relative safety between coauthors throughout the process, in particular as it related to the inclusion of LMA principles and the relevance, or lack thereof, within Sri Lankan dance. The American coauthor additionally led guided movement based on breath and movement themes that arose in the low-country dance classes. Facilitating the DMT sessions following the low-country dance classes allowed for additional reflection for both authors and helped to integrate the body knowledge developed throughout the sessions.

\section{Reflective Processing}

Following each session, we used descriptive journaling to reflect on main themes and questions that arose. After journaling, we discussed our reflections and what it was like to teach and/or lead as well as what it was like to be a participant. As a final method of 
reflection, we co-choreographed a short dance film (see Video 1) based on our embodied experience of the process of this shared scholarship and movement exchange. The video was created through discussing some of the main themes while learning and teaching the Rata Yakuma ritual, specifically how it relates to contemporary experiences of Sri Lankan women, including expectations from society around pregnancy, the lack of discussions around sexuality and intimacy, as well as responsibilities as mothers in the current time. The Sri Lankan coauthor selected certain images that resonated with her and which she felt could creatively represent the process, connecting back to identified themes. Both authors generated movement through improvising on movement themes and incorporated foundational movements from the ritual.

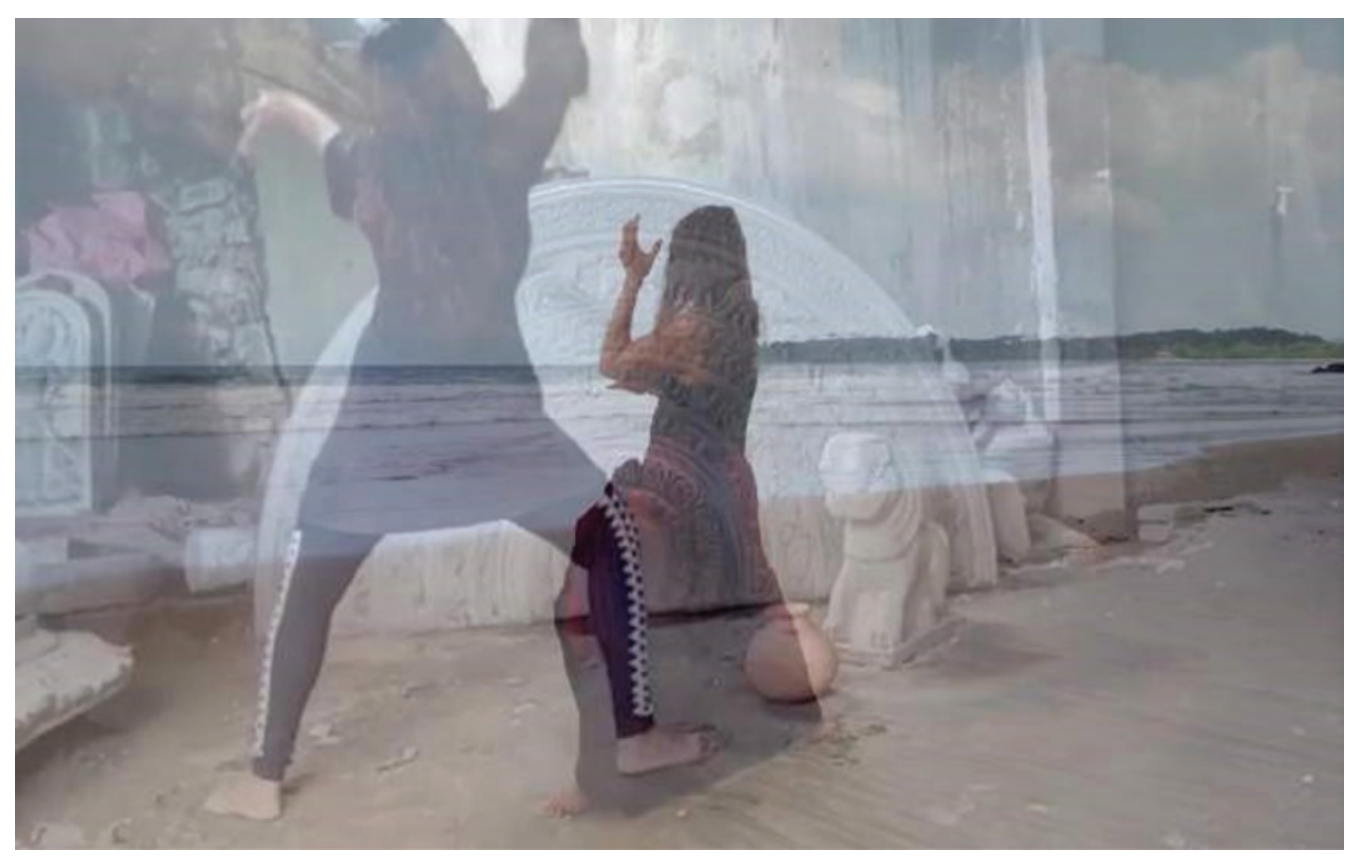

VIDEO 1 | Weaving Rata Yakuma (https://vimeo.com/581258415/5d941344d3).

\section{Reflections on the Collaborative Process}

\section{Main Themes}

The themes that emerged throughout our process are described through both a functional and an expressive movement lens. The balance between functional and expressive movement is important to name because our collaboration started from a technical place of learning foundational movement patterns of the low-country dance ritual. It was only after spending months in our process together that both authors began to look at the collaboration as a whole differently, with more focus on the emotional ramifications and impact of the collaboration on different aspects of our lives. 


\section{Mandiya as "Home"}

In our exploration, the theme of mandiya as "home base" and a place of stability and strength arose throughout our discussions. During one of the DMT sessions, the Sri Lankan coauthor identified that the intentional use of breath and placing importance on connecting with the breath while in this position led to greater ease of movement for her. The focus on connecting breath to movement was very new for the Sri Lankan author. This awareness has transcended into her role as a university lecturer, shifting her approach to teaching and facilitating choreography as well as how students learn movement by inviting more intentional focus on breath. For the American coauthor, the mandiya position elicited feelings of satisfaction, strength, and stability.

While exploring mandiya in a seated position during the DMT section of the session, the American coauthor acted as a participant-observer and mirrored the Sri Lankan author's movements as she began to improvise sections of the Nanumura episode of the ritual. The Sri Lankan coauthor was informed by the original movements from the ritual and began to do them in her own way. She reflected:

When thinking about my breath, I feel the gravity connection to the earth. It moves through my body like a passing current. So I effortlessly move my arms with the rhythm in my mind, closing my eyes. I feel the rhythmic drumming pattern. I feel the ritualistic moment patterns initially come out from my body. I was trying to feel them inwardly. I try to use them, and repeat them, again and again. It makes me more comfortable both in and out. Then I realize maybe this feeling could happen to the people who create these ritualistic movement patterns the first time. It is really wonderful...I feel my feet have touched the ground. While I was sitting, I felt like I was standing. It makes me more comfortable. Nothing comes to mind, just the rhythm.

It was during the teaching and learning of the nanumura (bathing section) of the Rata Yakuma ritual that the coauthors felt the weaving of their discussions, connections, movements, and internal processing. The following excerpts document the coauthors speaking wholeheartedly to each other about the process' impact on their personal and professional lives.

\section{A note from a Sri Lankan to an American}

When we started the process of teaching nanumura, your authentic interest in this ritual and the questions you asked about the nanumura and the kaviya (chant), sparked something in me; you took me to a place of feeling like I could clear my mind and body. When you were watching me, I felt more comfortable. I was thinking, "there is a person sitting in front of me, giving me their full attention." When thinking about that moment, I saw that someone was there to remove all of the anxiety and everything else bothering me. This is what is really happening in the ritual; people are watching, the doctor is there, the patient is there, and all of this helps them feel more comfortable.

The American coauthor reflected on her felt sense of expansiveness, comfort, and satisfaction while bearing witness to her coauthor's movement: 


\section{A note from an American to a Sri Lankan}

I was greatly impacted by this process of witnessing each other, especially these sparks and glimmers that were generated together in the moment. When you were improvising to the nanumura movements, it felt authentic and powerful to join you and mirror you during that time. I witnessed your spine swaying, how you found new rhythms in your arms, and I felt honored to be on this journey as you started to discover the warmth you felt throughout your body while replicating the bathing movements. It was soothing for me to follow you and it felt like we created more space for exploration of these everyday movements. In my body I was feeling comforted, and I thank you for allowing me to witness you in this moment.

\section{Increased Awareness and Connection to Specific Body Parts and Move- ment Patterns}

The exploration of mandiya led to additional awareness and connections to other body structures and patterns of movement. While engaging in the Authentic Movement practice, the Sri Lankan coauthor reflected on how she made mental movement patterns with her body. In our conversations, she disclosed: "I felt the patterns were connected to my body; I drew the movement patterns in my mind and they came out through the body." She thought about how ritualistic dancers who first developed these movements may have been connecting to mental movement patterns and visualizing these movements.

While exploring some of Hackney's (2008) patterns of connectivity, the Sri Lankan coauthor identified the rich presence of cross-lateral movements, especially present in walking, and the hand/arm movements that cross the midline of the body. There was additional awareness in the shoulder and head patterns while engaging in the walking patterns of the ritual when the focus was placed on connectivities. She also identified the connection between the movement in the hips, which helped to facilitate the lasya, or smooth, graceful movements in shoulders. She expressed curiosity around how being more aware of the foundational movements and increased awareness of placement of the body in mandiya, or placement of the arms, could ultimately assist with performing the ritual. This new focused awareness on the functionality of these movement patterns provided her space to focus on the expressive elements of the ritual and, ultimately, the emotional connections she was discovering.

Both authors reflected on the connectivity of the spine. For the Sri Lankan coauthor, the many movements of the spine helped to provide strength while sitting in the mandiya position: "I feel as if energy travels through the spine, some current passing on."

The American coauthor began to develop a new relationship to her hips throughout the process of learning low country and the ritual. She reflected: "I feel a warmth and tingling from my belly down, a very pleasant feeling in my hips, and an overall feeling of calm and motivating energy." Overall, both authors reflected on the power of kinesthetic empathy and curiosity of how both the patient as well as the audience/ community feels when watching this movement. 


\section{Connection to Nature}

Our explorations revealed the importance and role of nature and connecting to the earth that are elicited in the low-country dance rituals and how the low-country region, with its proximity to the beach and ocean, helps to facilitate movement. The natural rhythms such as the waves as well as the internal rhythms of the heartbeat and blood circulation are further complemented by the drumming.

While the American coauthor was visiting the southern part of Sri Lanka, where this ritual originated, she had the opportunity to explore what would happen when dancing some of the low-country movements on the beach, in proximity to the waves. Here are excerpts from her reflections:

Before doing namaskara, I took a few moments to take in the sounds of the waves, the gentle breeze, and the feeling of sand beneath my feet. It was cloudy but a few star systems were recognizable, specifically the Little Dipper. It was dark, with only the natural light from the moon lighting me. While performing the namaskara, I realized that dancing on the sand and the proximity to the water helped me really feel into the movement of the waves, as if they were entering my hips, swishing like water in a basin. I could feel the influence of the water and waves in my movement.

\section{Emotional and Personal Shifts}

By reflecting on our own emotional responses to both the ritual as well as our shared experience in DMT sessions, we began to ponder about the emotional responses of the women for whom this ritual is performed, which was one of the original intentions for exploring this ritual. The ritual in itself aims to address emotional themes around birth, sexuality, miscarriages, and pressures women experience and aims to be supportive of women experiencing these major life transitions. The Sri Lankan coauthor reflected on the transformation that occurred when she began to pay more attention to both the feelings in her body and mind that resulted when engaging in more improvisational movement as well as the functional and technical aspects of the movement.

She reflected: "I feel my weight is heavy in the beginning and becomes loosened, unbalanced, feeling into the stretch. I feel like I want to do more when the DMT session ends-similar to how I would imagine one feeling after participating in a ritual."

\section{A note from a Sri Lankan to an American: Discovering mutual influences on teaching, creativity, and spirit}

As a teacher, I always want to facilitate connections between students and teachers. When I started teaching you, the first thing I noticed is your ability to catch everything so quickly and your flexibility to attach to our movements. I felt very free to teach you and did not feel limited in any way. I felt more relaxed and felt comforted and connected by your clear starting and ending points of the sessions. This approach has fed into my teaching career. As a dancer and a choreographer, the mutual feedback and understanding made it easy to come up with choreography. We saw our own 
ideas expressed practically through the choreographic movements. I felt that this was enjoyable and healing for each other. The effort and time we spent to discuss really culminated in the video and showed the courage that we took to do this.

As a mother, I am always worrying about others and not always taking care of myself, as it is my way to take care of others. I love to work with others and collaborate, and through this process I felt like I finally took time for myself. I had time to think about myself during the moments I spent with you in the DMT sessions. Even if it is only 10-20 minutes, I now know the importance of taking this time as a mother, dancer, choreographer, and as a human.

On a personal level, I feel more connected to you. I did not feel like I was working with someone from another country or a foreigner. I felt like you are with us; you love our country and our culture. As a human, I felt more of the similarities and not the differences in moving with you.

\section{A note from an American to a Sri Lankan}

I am moved to hear you say that I am a part of Sri Lanka. You welcomed me into the culture, the ritual, the dance form, in a way that filled my heart. You invited me into this practice from the beginning, starting with the Ashirwada pooja. I felt like I was connecting to thousands of years of history. The honor and inclusion I felt being accepted to take part in the pooja encompassed my body. You helped me feel like I belong here even if I am not from here.

When I look back at my journal entries, I noted how often I felt tired, achy, sometimes a bit stressed, and sometimes a bit irritable before the sessions (we are still living very much in the pandemic, after all!). However, I always left the low-country sessions feeling more upbeat, energetic, and feeling like I could continue my day with ease and a bit more positivity. I realize that you helped me discover some important resources, both internal and external, that I can draw on not only in personal life, but also as a dance/movement therapist. When I feel stuck, whether creatively, or with a client, I find myself naturally doing the rhythmic hand movements you taught me; these movements helped me access more full bodied movements that allowed for me to get "unstuck."

The filming of the video was also very healing for me, in particular the moment I let the waves pass over me. I felt cleansed and was so relaxed. Your vision and suggestion that I let myself be enveloped by the water, of which I am in fact very afraid, and my wholehearted willingness to jump in, illuminates the trust we built and how we influenced each other.

The American coauthor tried to approach the process with a beginner's mind, despite some previous experience learning other South Asian dance forms and time living in the region. While approaching the process in this way, however, she continuously identified how her Western framework of learning and the need for detail and steps to be broken down sometimes contradicted the common approach of mirroring and mimicking the teacher that is used when teaching dance in Sri Lanka. This knowledge was very helpful in shifting the way this author approaches 
therapeutic settings in diverse cultural contexts as well as her creative practice. For example, this coauthor has been able to confront perfectionistic tendencies rooted in her Western upbringing, by allowing herself to be more present in the witnessing of the core essence of the movement, whether it is in a choreographic space, or in a therapeutic space.

\section{Conclusion}

The process of this shared exchange generated rich discussions and increased awareness around how we can enter dance and therapeutic spaces with cultural sensitivity, especially for cross-cultural collaborations. Our first guiding question centered around potential DMT techniques and approaches that could be applicable within the education sector and the way dance pedagogy is approached in Sri Lanka. The Sri Lankan coauthor identified the benefits of incorporating ample time for discussion and reflections for students, just as one would in a DMT session; creating clear beginning and endings of classes to help foster camaraderie among students; including more breath work in her classes; and on a personal level, the importance of taking time for herself to recuperate and for self-care. With regards to our second guiding question connected to potential movements, aesthetics, and elements from low-country dance healing rituals that could inform the way DMT sessions in Sri Lanka are facilitated in aculturally sensitiveway, the American coauthor found that certain rhythmic movement patterns present in low-country dance, in particular hand movements, could serve as an effective way to transition, recuperate, and energize before or after sessions and to help her get "unstuck" when working alongside clients. Our reflections also illuminated the importance of not reducing the inherent therapeutic value of healing rituals by trying to place a Western lens on the movement and the historical practice. Although at times we experienced shared elements between DMT and the low-country ritual, we tried not to compare the indigenous practices to DMT. Ultimately, our exploration revealed that we needed to do more inward and personal exploration of the dance form and DMT-based approaches, and more importantly, continue to create space for discussions around this topic island wide. Through this collaboration, we planted the seeds for a fruitful and meaningful long-term exchange.

We hope that this exploration sets the foundation for more formal research in the future, not only from these authors, but from other South Asian dance researchers and practitioners. Future explorations could include a deeper analysis into possible benefits and drawbacks of integrating DMT and healing dance forms that have existed for millennia, or perhaps the development of a movement analysis system that is not rooted in Western approaches and accounts for the unique elements of Sri Lankan dance forms. We also encourage more initiatives for coauthorship among Eastern and Western dance and DMT practitioners to continue this important conversation.

\section{Conflicts of Interest}

The authors declare no conflict of interest. 


\section{About the Authors}

Ashley Fargnoli, MA, LCPC, BC-DMT, is a dance/movement therapist and lecturer working alongside trauma and conflict affected populations. She has presented her work in the United States and internationally, including in Sri Lanka, India, Nepal, Switzerland, and the Balkans. Ashley has lived in Bosnia and Herzegovina and Sri Lanka, where she implemented numerous dance reconciliation projects, and in Kolkata, India, where she worked with survivors of human trafficking. Ashley has a MA in Dance/Movement Therapy and Counseling program from Columbia College, Chicago, and also holds an MA in Cultural Project Management from the Institute of Political Studies (France). Ashley has taught Expressive Arts Therapy at the School of the Art Institute, Chicago, and was a Fulbright Scholar at the University of Peradeniya, Sri Lanka, during the 2019-2020 academic year.

Dhanushka Seneviratne, MA, BA (fine arts special $1^{\text {st }}$ class honors), is a dancer, choreographer, and lecturer at the University of Kelaniya in Sri Lanka. She has been a professional choreographer for more than 20 years and has traveled to Thailand and Pakistan as a choreographer. She has won international and national awards for her choreography and won the best actress award in the national ballet competition festival in 2007. She has worked as a dance teacher for national high schools and cultural centers for many years. Dhanushka is currently a MPhil Reader at the University of Peradeniya. Her collaborative experience includes conducting workshops on drama exercises and techniques, workshops on life skills through theater, and collaborative choreography workshops. Her current research interests include collaborative research on Sri Lanka's low-country dance and DMT.

\section{References}

Gladding, K. (2012, October 17). Treasured tradition [Blog post]. Retrieved June 26, 2021 from http:// thirdeye2005.blogspot.com/2012/10/.

Hackney, P. (1998). Making connections: Total body integration through Bartenieff Fundamentals. Gordon $\&$ Breach.

Jayatunge, M. (2017). Riddi Yāgaya: A healing ritual of Sri Lanka. Journal of the Royal Asiatic Society of Sri Lanka, 62(1), 81-93. doi:10.2307/45219022.

Nichols, E. (2019). Moving blind spots: Cultural bias in the movement repertoire of dance/movement therapists. Unpublished master's thesis, Lesley University, Cambridge, MA.

Pallaro, P. (Ed) (1999). Authentic movement: Essays by Mary Starks Whitehouse, Janet Adler and Joan Chodorow. Jessica Kingsley.

Rajapakse, W. (2004). On the origin and early history of Sri Lankan dancing: Between spirit beliefs and great tradition, appeasement of the gods, and healing methods. The World of Music, 46(3), 65-78. Retrieved February 10, 2021, from http://www.jstor.org/stable/41699592.

Satkunaratnam, A. (2013). Staging war: Performing Bharata Natyam in Colombo, Sri Lanka. Dance Research Journal, 45(1), 81-108. Retrieved June 25, 2021, from http://www.jstor.org/stable/23524727.

Stegeborn, W. (2004). The disappearing Wanniyala-aetto ('Veddahs') of Sri Lanka: A case study. Nomadic Peoples, 8(1), 43-63. Retrieved June 25, 2021, from http://www.jstor.org/stable/43123716.

Third Eye Local Skills and Knowledge Group. (2012, May 9). Performance in the place of war [Blogpost]. Retrieved June 26, 2021 from http://thirdeye2005.blogspot.com/2012/05/. 